\title{
Impact Of An Eductional Program On: Knowledge And Practice Of Hepatitis C Infected Patients Treated By Pegylated Interferon And Ribavirin.
}

Shimaa Mohammed Abdou Rizk ; Prof. Dr. Magda Abd-Elaziz; Prof. Dr. Ayman Abd-El ghafar; Dr. Dina El-tabey Sobeh

M.Sc. Medical Surgical nursing, Mansoura University; Professor of Medical Surgical nursing department, Faculty of Nursing , Ain Shams University; Professor of Internal Medicine, Faculty of Medicine, Mansoura University; Lecturer of Medical Surgical Nursing, Faculty of Nursing, Port- Said University.

\begin{abstract}
Background: Hepatitis C virus is an important public health problem in both developing and developed countries, while in Egypt there was the highest prevalence of hepatitis C in the world. Aim: aim of the study evaluate the impact of an educational program on knowledge and practice among patients infected with hepatitis $\mathrm{C}$ virus who are treated with Pegylated Interferon and Ribavirin.Subject and Methods: The research design was a quasi experimental design. The sample consisted of 100 patients with hepatitis $\mathrm{C}$ for study group and 50 patients control group A purposive who are age and sex matche as a positive control group. Data was collected through an interviewing questionnaire sheet, which including two tools, first; socio-demographic characteristics, patients' history, past medical history and present medical history, second; assessment of knowledge and practice.Results: The study results revealed that, there was a highly statistically significant difference between pre and post program mean score in the study group after implementation of the educational program in total knowledge and practice with $(p \leq 0.001)$, while in the control group there was no statistically significant difference related to knowledge between pre and post program with $(\mathrm{p}<0.125)$ while in practice with $(\mathrm{p} \leq 1.000)$. Conclusion: The study concluded that a highly statistically significant improvement in total knowledge, practice of the study group after implementation of the educational program. In the control group there was no statistically significant improvement. Recommendations: The study recommended Promotion and enhancement of the self-care modalities to the patient; a strict written instruction with pictures about disease process, allowed foods, rest and physical activities and follow up should be continued after termination of the treatment through a rehabilitation program.
\end{abstract}

Keywords: hepatitis C, knowledge, practice, interferon, Ribavirin, educational program (EP). 


\section{INTRODUCTION}

Hepatitis C virus (HCV) is an infectious disease that was discovered in 1989, in which most people had no symptoms until the virus causes liver damage, which can take 10 or more years to happen and leads to chronic liver disease, liver cirrhosis and cancer, so the diagnosis of HCV can also affect the person's quality of life, finances, productivity, and psychological status Groessl, et al., (2011). Moreover, HCV represents a challenge to the health and well-being of the patients and health care system Sarasin \& Filipowicz, (2010); Marcellin, et al.,( 2011).

The World Health Organization (WHO) declared that, HCV is a global health problem affecting 130-170 million people worldwide. In Egypt, it became a public health problem and its incidence was increased, added to its prevalence, which is the highest reported worldwide. The overall prevalence of patient admission in the hospitals for HCV treatment had been increased at a very high rate over the past years. Moreover, many publications suggest that, over 15.0\% of people in Egypt are infected, which equal ten times greater than any other country in the world Ahmed, \& Abdel Al, 2008; Mohsen, et al.,( 2011).

Remarkable progress has been made in the management of hepatitis $\mathrm{C}$ in recent years and combination therapy (Peginterferon/Ribavirin) was the standard of care. Interferon is a substance naturally produced by the body to defend itself from infections and regulating cell function including the hepatitis $\mathrm{C}$ virus and tumors. Interferon was the first proven treatment for $\mathrm{HCV}$, but it is effective for few people. It was administered as an injection taken once a week over a period of 24-48 weeks Thomas, \& Zoulim, (2012).

Ribavirin, called nucleoside analogues, works by stopping the virus from spreading inside the body, it presents in the form tablets, which taken three times per day. Younger patients who have mild liver disease and fewer virus particles in the liver usually respond better to interferon and ribavirin treatment than others. Nadeem et al., 2007 and Noghabi et al., (2010).

In several large trials of $\mathrm{HCV}$ treatment, a wide variety of side effects have been encountered, which usually are problematic for a significant proportion of patients. Major adverse events can occur, but life-threatening adverse events have been rare in large surveys. Moreover, about 10.0 and 15.0 percent of patients report chronic intolerable side effects and discontinue the treatment. Higher doses tend to give higher rates of adverse events. Most symptoms can be managed with medical intervention and dose reduction. Khalid, et al., (2009); Stefan, et al., (2011); Velmishi, et al.,( 2012). 
Educational programs play an important role in improvement of patients' level of knowledge about HCV among HCV-infected patients that result in a marked increase in willingness to accept $\mathrm{HCV}$ treatment and may promote their compliance to treatment as well as improve their quality of life Helbling, et al.,( 2008).

Patients who are infected with $\mathrm{HCV}$, have limited knowledge and practice of $\mathrm{HCV}$ disease while, improvement in HCV knowledge can influence a patient's decision to explore and initiate HCV therapy by providing educational programs for patients; it may promote their compliance to treatment as well as improve their quality of life. Patient-centered approach to health care in $\mathrm{HCV}$-infected vulnerable population is likely to result in higher compliance with pursuing HCV health care and potentially create efficiencies in the health system to better access specialty care for these individuals Sharif, et al.,( 2005).

Nursing profession in such way helps the nurse in arriving at a decision, prediction, and evaluation, nurse is back bone for evaluating the care given to patient and measure patients' satisfaction with the care, this can be achieved through the nursing process, which is the tool and the method composed of assessment, diagnosis, planning, implementation and evaluation Ramadan,( 2006).

\section{AIM OF STUDY}

Evaluate the impact of educational program on knowledge and practice among patients infected with hepatitis $\mathrm{C}$ virus who are treated with pegylated interferon and ribavirin.

\section{SUBJECT AND METHODS}

The design for this study was (a cohort research design). A purposive sample of (100) patients with hepatitis $C$ for study group and control group (50) patients who are age and sex matched as a positive control group.

\section{Tools for data collection}

Data was collected through an interviewing questionnaire sheet, which including two tools

1- Socio-demographic characteristics, patients' history, past medical history and present medical history.

2- Assessment of knowledge and practice.

Tool I (Appendix I): Structured interviewing questionnaire sheet was developed and consisted of two parts:

\section{Part 1:Socio-demographic Data Sheet:}

It was consisted of general characteristics of patients subjected to the study and composed of ten questions, including: sex, age, marital status, residence, level of 
education, job, work nature, work status after disease, monthly income, and treatment cost.

\section{Part 2: Medical History Sheet:}

\section{a) Past Medical History:}

It was constructed and reviewed by utilizing the most recent and relevant literatures, which includeda series of questions to elicit patient's knowledge related to past medical history, it was composed of six questions, which included family history of disease, degree of relatives, history of hospitalization, history of surgical operations, blood transfusion, anti-bilharzias treatment and dentist visits.

\section{b) Present Medical History:}

It was developed by the researcher to collect data about the present medical status, it is composed of five questions, which includedduration of disease, how diagnosed the disease, symptoms associated with the disease, when starting treatment, and side effects related to disease.

\section{Tool II: Patient's Knowledge and Practice Assessment Sheet (Appendix II):}

\section{It was composed of two parts:}

\section{Part 1:Knowledge Assessment Sheet:}

It was constructed and reviewing by utilizing the most recent and relevant literatures, which included a series of questions to elicit patients' knowledge related to chronic hepatitis $\mathrm{C}$ virus, it was composed of (18)questions and included a definition, mode of transmission, signs and symptoms, complications, investigations, nutrition, treatment ways, action of interferon, indication for administration, contraindication for administration, site of injection, time of injection, duration of treatment, recommendations for treatment, side effects related to gastrointestinal tract, nervous system, and other side effects related to treatment, and recommendations should be followed for positive effect of treatment.

\section{Scoring System:}

The answers were evaluated using model key answer prepared by the researcher; the score two for correct answers who exceed $60 \%$ of total score of question and zero for incorrect answers which were similar to previous study conducted by (Hegazy et al., 2013). The total knowledge score was (36):

- Satisfactory if score $\geq 60.0 \%$ of the maximum score.

- Unsatisfactory if score $<60.0 \%$ of the maximum score.

\section{Part2: Practice Assessment Sheet:}

It was constructed and reviewed by utilizing the most recent and relevant literatures, which included a series of questions to elicit patient's practice about hepatitis $\mathrm{C}$ virus 
related to treatment side effects, it's composed of ten multiple choice questions, which included what can you do to overcome vomiting, fatigue, nausea and anorexia, constipation, diarrhea, insomnia, anxiety, depression, headache, and injection site inflammation.

\section{Scoring System:}

Practice questionnaire sheet consisted of 10 multiple choice questions, whereasthe answers were evaluated using a model key answer prepared by the researcher, and the score two for correct answers who exceed $70 \%$ of total score of question, and zero score for incorrect answers which was similar to previous study conducted by (Hegazy et al., 2013). The total practice score was (20), who considered:

- Adequately done if score $\geq 70.0 \%$ of the maximum score.

- Inadequately done if score $<70.0 \%$ of the maximum score.

\section{RESULTS}

Table (1) : illustrates that, (40.0\%) of the study group and $(34.0 \%)$ of the control group are in the same age group from 40 years to less than 50 years old with mean age $(39.70 \pm 7.74)$ and $(39.560 \pm 9.532)$ respectively .

As regards to level of education, (35.0\%) of the study group and (48.0\%) of the control group are secondary education. Regarding patient's occupation, $27.0 \%$ of the study group and $34.0 \%$ of the control group are housewives, $24.0 \%$ of the study group are farmers, and $34.0 \%$ of the control group are workers. Concerning work nature, $(64.0 \%)$ of the study group and about $(62.0 \%)$ of the control group both their work requires both physical and mental effort. In relation to work after disease, it is clear from the table that, $(66.0 \%, \& 55.0 \%)$ from study group and control group respectively work part of the time. Concerning family income, $(88.0 \%)$ of the study group and control group has not enough family income while, $(2.0 \%, \& 4.0 \%)$ of the study group and control group respectively has enough family income.

Table (2): Reveals that, $69.0 \%$ of the study group suffering from fatigue, while in the control group, $64.0 \%$ suffering from fatigue and $(88.0 \%)$ of them are suffering from anorexia. Concerning treatment coverage, $(81.0 \% \& 96.0 \%)$ of the study group and control group respectively, receive their treatment from government. As regards to treatment duration, $(93.0 \% \& 86.0 \%)$ of the study group and control group spent less than six months in their treatment. Regarding family history, $40.0 \%$ of the study group and $36.0 \%$ of the control group have positive family history of first degree.

Table (3): Shows that, there is a highly statistically significant difference between pre and post program mean score in the study group after implementation of the educational program in total knowledge with $(\mathrm{p} \leq 0.001)$, while there is no statistically 
significant difference between pre and post program in the control group with $(\mathrm{p}<0.125)$.

Table (4): Shows that, there are highly statistically significant differences between pre and post program scores in the study group after implementation of the educational program in total practice scores with $\left(p \leq 0.001^{* *}\right)$, while there are no statistically significant differences between pre and post program scores in the control group with $(\mathrm{p} \leq 1.000)$.

Table( 5): shows that, there was a highly statistically significant relation between the study group and control group regarding knowledge improvement with $(\mathrm{p}<0.000$ ), while thereis a statistically significant relation between age and knowledge improvement with $\left(\mathrm{p}<0.011^{*}\right)$.

Table (6): shows that, there is a highly statistical significant relation between the study group and control group and practice improvement with $\left(\mathrm{p} \leq 0.000^{* *}\right)$, where there are no statistically significant relation between general characteristics and practice improvement. 
Table (1): Percentage distribution of the study sample (study group and control group) according to their general characteristics $(\mathrm{N}=150)$.

\begin{tabular}{|c|c|c|c|c|c|c|}
\hline \multirow{3}{*}{$\begin{array}{l}\text { Socio-demographic } \\
\text { characteristics }\end{array}$} & \multicolumn{4}{|c|}{ Groups } & \multirow{3}{*}{$\begin{array}{l}\mathbf{p} \\
\text { value }\end{array}$} & \multirow{3}{*}{$\begin{array}{l}\text { Chi- } \\
\text { square }\end{array}$} \\
\hline & \multicolumn{2}{|c|}{$\begin{array}{l}\text { Study group } \\
\mathrm{N}=100\end{array}$} & \multicolumn{2}{|c|}{$\begin{array}{l}\text { control group } \\
\mathrm{N}=50\end{array}$} & & \\
\hline & $\mathrm{N}$ & $\%$ & $\mathrm{~N}$ & $\%$ & & \\
\hline \multirow{4}{*}{$\begin{array}{l}18- \\
30- \\
40- \\
50-\end{array}$} & 16 & 16.0 & 8 & 16.0 & \multirow{5}{*}{0.923} & \multirow{5}{*}{0.96} \\
\hline & 26 & 26.0 & 17 & 34.0 & & \\
\hline & 40 & 40.0 & 17 & 34.0 & & \\
\hline & 18 & 18.0 & 8 & 16.0 & & \\
\hline Mean \pm SD & \multicolumn{2}{|c|}{$39.70 \pm 7.74$} & \multicolumn{2}{|c|}{$39.560 \pm 9.532$} & & \\
\hline \multicolumn{5}{|l|}{ Level of education } & & \\
\hline \multirow{4}{*}{$\begin{array}{l}\text { Illiterate } \\
\text { Read \& write } \\
\text { Secondary } \\
\text { Universal }\end{array}$} & 25 & 25.0 & 13 & 26.0 & \multirow{4}{*}{0.309} & \multirow{4}{*}{3.591} \\
\hline & 24 & 24.0 & 9 & 18.0 & & \\
\hline & 35 & 35.0 & 24 & 48.0 & & \\
\hline & 16 & 16.0 & 4 & 8.0 & & \\
\hline \multicolumn{7}{|l|}{ Occupation } \\
\hline \multirow{5}{*}{$\begin{array}{l}\text { Employee } \\
\text { Farmer } \\
\text { House Wife } \\
\text { Worker } \\
\text { Not Working }\end{array}$} & 18 & 18.0 & 2 & 4.0 & \multirow{5}{*}{0.166} & \multirow{5}{*}{6.478} \\
\hline & 24 & 24.0 & 11 & 22.0 & & \\
\hline & 27 & 27.0 & 17 & 34.0 & & \\
\hline & 25 & 25.0 & 17 & 34.0 & & \\
\hline & 6 & 6.0 & 3 & 6.0 & & \\
\hline \multicolumn{7}{|l|}{ Work nature } \\
\hline \multirow{4}{*}{$\begin{array}{l}\text { Mental Effort } \\
\text { Physical Effot } \\
\text { Both Mental and Physical } \\
\text { Not Working }\end{array}$} & 5 & 5.0 & 5 & 10.0 & \multirow[t]{4}{*}{0.706} & \multirow[t]{4}{*}{1.396} \\
\hline & 25 & 25.0 & 11 & 22.0 & & \\
\hline & 64 & 64.0 & 31 & 62.0 & & \\
\hline & 6 & 6.0 & 3 & 6.0 & & \\
\hline Work All Time & 23 & 23.0 & 17 & 34.0 & \multirow{4}{*}{0.244} & \multirow{4}{*}{4.169} \\
\hline Work Part Of Time & 66 & 66.0 & 25 & 50.0 & & \\
\hline Leave Work & 5 & 5.0 & 5 & 10.0 & & \\
\hline Not Working & 6 & 6.0 & 3 & 3.0 & & \\
\hline \multicolumn{7}{|l|}{ Family income } \\
\hline Not Enough & 88 & 88.0 & 44 & 88.0 & \multirow{3}{*}{44} & \multirow{3}{*}{88.0} \\
\hline Enough & 10 & 10.0 & 4 & 8.0 & & \\
\hline More Than Enough & 2 & 2.0 & 2 & 4.0 & & \\
\hline
\end{tabular}


Table (2) : Medical history data of the studied groups. $(\mathrm{N}=150)$.

\begin{tabular}{|c|c|c|c|c|c|c|}
\hline \multirow{3}{*}{ Health history } & \multicolumn{4}{|c|}{ Groups } & \multirow{3}{*}{ P value } & \multirow{3}{*}{$\begin{array}{l}\text { Chi- } \\
\text { square }\end{array}$} \\
\hline & \multicolumn{2}{|c|}{$\begin{array}{l}\text { Study group } \\
\mathrm{N}=100\end{array}$} & \multicolumn{2}{|c|}{$\begin{array}{l}\text { control group } \\
\mathrm{N}=50\end{array}$} & & \\
\hline & $\mathrm{N}$ & $\%$ & $\mathrm{~N}$ & $\%$ & & \\
\hline \multicolumn{7}{|c|}{ Symptoms of \# HCV } \\
\hline \multirow{6}{*}{$\begin{array}{l}\text { Fatigue } \\
\text { Anorexia } \\
\text { Nausea } \\
\text { Fever } \\
\text { Abdominal Pain } \\
\text { Others }\end{array}$} & 69 & 69.0 & 32 & 64.0 & 0.538 & 0.379 \\
\hline & 64 & 64.0 & 44 & 88.0 & 0.002 & 9.524 \\
\hline & 36 & 36.0 & 21 & 42.0 & 0.475 & 0.509 \\
\hline & 15 & 15.0 & 19 & 38.0 & 0.002 & 10.65 \\
\hline & 35 & 35.0 & 7 & 14.0 & 0.007 & 7.292 \\
\hline & 6 & 6.0 & 7 & 14.0 & 0.101 & 2.695 \\
\hline \multicolumn{7}{|c|}{ Treatment coverage } \\
\hline \multirow{3}{*}{$\begin{array}{l}\text { Governmental } \\
\text { Work } \\
\text { Health Insurance }\end{array}$} & 81 & 81.0 & 48 & 96.0 & \multirow{3}{*}{0.043} & \multirow{3}{*}{6.272} \\
\hline & 1 & 1.0 & 0 & 0.0 & & \\
\hline & 18 & 18.0 & 2 & 4.0 & & \\
\hline \multicolumn{7}{|c|}{ Treatment duration } \\
\hline \multirow{2}{*}{$\begin{array}{l}<6 \text { Months } \\
>6 \text { Months }\end{array}$} & 93 & 93.0 & 43 & 86.0 & \multirow[t]{2}{*}{0.165} & \multirow[t]{2}{*}{1.93} \\
\hline & 7 & 7.0 & 7 & 14.0 & & \\
\hline \multicolumn{7}{|l|}{ Family History } \\
\hline \multirow{4}{*}{$\begin{array}{l}\text { No } \\
\text { Yes } \\
\text { If yes relative } \\
\text { First degree } \\
\text { Second degree }\end{array}$} & 47 & 47.0 & 29 & 49.0 & & \\
\hline & 53 & 53.0 & 21 & 42.0 & 0.204 & 1.614 \\
\hline & 40 & 40.0 & 18 & 36.0 & 0.635 & 0.225 \\
\hline & 13 & 13.0 & 3 & 6.0 & 0.19 & 1.714 \\
\hline
\end{tabular}


Table (3): Comparison of Patient's total knowledge score between the study group and control group before and after program implementation. $(\mathrm{N}=150)$

\begin{tabular}{|l|l|l|l|l|}
\hline \multicolumn{1}{|c|}{$\begin{array}{c}\text { Total } \\
\text { knowledge }\end{array}$} & \multicolumn{2}{|l|}{ Groups } & \\
\cline { 2 - 4 } Item & Pre program & Post program & $\begin{array}{l}\text { Chi- } \\
\text { Square }\end{array}$ & p- value \\
\cline { 2 - 5 } & Mean \pm SD & Mean \pm SD & & \\
\hline Study group & $13.24 \pm 5.42$ & $27.41 \pm 8.25$ & 2.557 & $0.001 * *$ \\
\hline Control group & $16.18 \pm 4.92$ & $16.96 \pm 5.33$ & 45.014 & 0.125 \\
\hline
\end{tabular}

Highly significant $(\mathrm{p}<0.001 * *)$

Table (4): Patient's total practice score before and after program implementation $(\mathrm{N}=150)$

\begin{tabular}{|c|c|c|c|c|}
\hline Total & Groups & & \multirow{3}{*}{$\begin{array}{l}\text { Chi- } \\
\text { square }\end{array}$} & \multirow{3}{*}{ p- value } \\
\hline \multirow{2}{*}{ Item } & Pre program & Post program & & \\
\hline & Mean \pm SD & Mean \pm SD & & \\
\hline Study group & 4. $480 \pm 5.303$ & $14.710 \pm 3.641$ & 0.158 & $<0.001 * *$ \\
\hline control group & $3.600 \pm 5.010$ & $4.660 \pm 5.906$ & 81.907 & 1.000 \\
\hline
\end{tabular}

Highly significant $(\mathbf{p}<0.001 * *)$ 
Table (5): Relation between general characteristics and knowledge improvement between study group and the control group. $(\mathrm{N}=150)$

\begin{tabular}{|c|c|c|c|c|c|}
\hline \multirow[t]{2}{*}{ Item } & \multirow{2}{*}{$\begin{array}{l}\text { Numbe } \\
\text { r }\end{array}$} & \multicolumn{2}{|c|}{$\begin{array}{l}\text { Knowledge } \\
\text { improvement }\end{array}$} & \multirow{2}{*}{$\begin{array}{l}\text { Chi- } \\
\text { square }\end{array}$} & \multirow{2}{*}{$\begin{array}{l}\text { P- } \\
\text { value }\end{array}$} \\
\hline & & No. & $\%$ & & \\
\hline \multicolumn{6}{|l|}{ Group } \\
\hline Control & 50 & 4 & 8.0 & \multirow{2}{*}{60.024} & \multirow{2}{*}{$0.000 * *$} \\
\hline study & 100 & 75 & 75.0 & & \\
\hline \multicolumn{6}{|l|}{ Sex } \\
\hline Male & 93 & 53 & 57.0 & \multirow{2}{*}{1.834} & \multirow{2}{*}{0.176} \\
\hline Female & 57 & 26 & 45.6 & & \\
\hline \multicolumn{6}{|l|}{ Age } \\
\hline$<30$ & 17 & 4 & 23.5 & \multirow{4}{*}{11.109} & \multirow{4}{*}{$0.011^{*}$} \\
\hline $30-$ & 55 & 32 & 58.2 & & \\
\hline $40-$ & 60 & 37 & 61.7 & & \\
\hline $50+$ & 18 & 6 & 33.3 & & \\
\hline \multicolumn{6}{|l|}{ Marital Status } \\
\hline Single & 12 & 5 & 41.7 & \multirow{4}{*}{2.066} & \multirow{4}{*}{0.559} \\
\hline Married & 122 & 66 & 54.1 & & \\
\hline Divorced & 4 & 3 & 75.0 & & \\
\hline Widow & 12 & 5 & 41.7 & & \\
\hline \multicolumn{6}{|l|}{ Residence } \\
\hline Rural & 133 & 70 & 52.6 & \multirow[t]{2}{*}{0.001} & \multirow[t]{2}{*}{0.981} \\
\hline Urban & 17 & 9 & 52.9 & & \\
\hline \multicolumn{6}{|c|}{ Educational Level } \\
\hline Universal & 20 & 10 & 50.0 & \multirow{4}{*}{0.104} & \multirow{4}{*}{0.991} \\
\hline Secondary & 59 & 31 & 52.5 & & \\
\hline Read and write & 33 & 18 & 54.5 & & \\
\hline Universal & 38 & 20 & 52.6 & & \\
\hline \multicolumn{6}{|l|}{ Job } \\
\hline Employee & 20 & 16 & 80.0 & \multirow{5}{*}{8.842} & \multirow{5}{*}{0.065} \\
\hline Farmer & 35 & 16 & 45.7 & & \\
\hline House Wife & 44 & 19 & 43.2 & & \\
\hline Worker & 42 & 24 & 57.1 & & \\
\hline Not Working & & 4 & 44.4 & & \\
\hline
\end{tabular}

Highly statistically significant difference, $(\mathbf{P}<0.001 * *)$.

Significant $(\mathrm{P} \leq \mathbf{0 . 0 5 *})$ 
Table (6): Relation between general characteristics and practice improvement between study group and the control group. $\mathrm{N}=150$

\begin{tabular}{|c|c|c|c|c|c|}
\hline \multirow{2}{*}{ Item } & \multirow{2}{*}{ Number } & \multicolumn{2}{|c|}{ Practice improvement } & \multirow{2}{*}{$\begin{array}{l}\text { Chi- } \\
\text { square }\end{array}$} & \multirow{2}{*}{\begin{tabular}{|l|}
$\mathrm{P}-$ \\
value
\end{tabular}} \\
\hline & & No & $\%$ & & \\
\hline \multicolumn{6}{|l|}{ Group } \\
\hline control & 50 & 2 & 4.0 & \multirow{2}{*}{67.21} & \multirow{2}{*}{$0.000 * *$} \\
\hline study & 100 & 75 & 75.0 & & \\
\hline \multicolumn{6}{|l|}{ Sex } \\
\hline Male & 93 & 51 & 54.8 & \multirow{2}{*}{1.204} & \multirow{2}{*}{0.273} \\
\hline Female & 57 & 26 & 45.6 & & \\
\hline \multicolumn{6}{|l|}{ Age } \\
\hline$<30$ & 17 & 9 & 52.9 & \multirow{4}{*}{0.237} & \multirow{4}{*}{0.971} \\
\hline $30-$ & 55 & 27 & 49.1 & & \\
\hline $40-$ & 60 & 32 & 53.3 & & \\
\hline $50+$ & 18 & 9 & 50.0 & & \\
\hline \multicolumn{6}{|l|}{ Marital Status } \\
\hline Single & 12 & 7 & 58.3 & \multirow{4}{*}{1.359} & \multirow{4}{*}{0.715} \\
\hline Married & 122 & 63 & 51.6 & & \\
\hline Divorced & 4 & 1 & 25.0 & & \\
\hline Widow & 12 & 6 & 50.0 & & \\
\hline \multicolumn{6}{|l|}{ Residence } \\
\hline Rural & 133 & 68 & 51.1 & \multirow{2}{*}{0.020} & \multirow{2}{*}{0.888} \\
\hline Urban & 17 & 9 & 52.9 & & \\
\hline \multicolumn{6}{|c|}{ Educational Level } \\
\hline Universal & 20 & 10 & 50.0 & \multirow{4}{*}{2.77} & \multirow{4}{*}{0.428} \\
\hline Secondary & 59 & 27 & 45.8 & & \\
\hline Read and write & 33 & 21 & 63.6 & & \\
\hline Universal & 38 & 19 & 50.0 & & \\
\hline \multicolumn{6}{|l|}{ Job } \\
\hline Employee & 20 & 11 & 55.0 & \multirow{5}{*}{1.283} & \multirow{5}{*}{0.864} \\
\hline Farmer & 35 & 20 & 57.1 & & \\
\hline House Wife & 44 & 20 & 45.5 & & \\
\hline Worker & 42 & 21 & 50.0 & & \\
\hline Not Working & & 5 & 55.6 & & \\
\hline
\end{tabular}

Highly statistically significant, $(P<0.001 * *)$.

Significant $(P \leq \mathbf{0 . 0 5 *})$ 


\section{DISCUSSION}

Lankarani (2004) stated that, improving compliance with therapy can be enhanced by some measures such as patient education, close follow up, adequate treatment of side effects and minimizing dose changes. While, lack of expertise in the proper management of these side effects as well as lack of educating patient lead to higher rates of drug discontinuation or dose reduction with the resultant lower efficacy of treatment.

\section{First: (Part I) General Characteristics of the studied patients:}

The present study clarified that, more than two thirds of studied patients (study \&control groups) at age group between 40 to less than 50 years, more than two thirds of patient in study group and more than half of patients in control group were male, the majority of the patients in the studied patients (study \&control groups) were married while the minority of both groups were widow and single, and the majority of both group were from rural area while the minority of both groups were from the urban area.

Moreover, more than one third of the study group and less than half of control group receive secondary education while about one third for both groups was illiterate, about one third of study group were farmers, and about one third for the same group were workers while more than one third of control group were farmers and more than one third for the same group were workers, more than half of both groups (study \& control) the work nature required both physical and mental effort.

Socio-demographic characteristics of present study proved that, the age of studied patients could be attributed to the chronicity of $\mathrm{HCV}$ infection in about $75.0 \%$ of patients while the majority of the patients in the study were married might be due to the same age groups of the studied sample. The possible explanation for the large percent that are infected from rural areas may be due to lack of health care centers, decrease population health awareness in Egyptian rural areas and patient's occupation as a farmer and liabilities for bilharzias infection. 
The researcher opinion related to the educational level of the studied sample, might be due to the majority of patients were from rural areas with less attention to education that also explain study sample that had not enough monthly income to cover their needs, in addition to costs of required periodical investigations to follow the response of the treatment, which add a burden on the patients. This could be due to slightly near half of the studied sample were farmers and workers in addition to low socioeconomic status for most Egyptian population.

\section{Part II: Medical History of the Studied Sample:}

Concerning the way of discovering disease, about one third of the studied subjects (study \&control groups) were discovered to have HCV disease by chance; this might be due to the majority of patients were from rural area and half of the patients were illiterate and farmers, so they did not seek medical care until the disease become worse.

The current study findings were supported by Sterling and Bralow (2006), who conducted study for extrahepatic manifestations of hepatitis $\mathrm{C}$ virus and found that, almost of patients with acute and chronic HCV infection are asymptomatic. This finding is in accordance with McHutchison, Goodman, and Patel (2010), who observed that, more than one fourth of the studied patients were discovered to have HCV disease by symptoms.

As regard to symptoms, the most common symptoms were fatigue and anorexia; this was supported by Abdel Hady (2011), who studied the quality of life in patients with liver cirrhosis at Mansoura hospitals and clarified that, most of the participants suffer from abdominal pain, and more than half of them has loss of appetite. This finding is in disagreement with $\boldsymbol{A b d}$ El-Shahed (2008), who conducted study about factors affecting quality of life of patients with liver cirrhosis, found that, more than one third of the studied patients had abdominal pain, and most of them had dyspnea.

In relation to family history, two fifth of the study group and more than one third of the control group had a positive family history of chronic HCV with the first degree of relatives. This could be due to HCV is an infectious disease and may spread among the patient's family due to the illegal practice of universal health precautions. The 
finding was supported by Schwarzinger, et al., (2004); Garieb (2008), who conducted study about chronic hepatitis $\mathrm{C}$ virus infection: does it really impact healthrelated quality of life?, they reported that, more than one fourth of the studied patients' relatives had family history of hepatitis $\mathrm{C}$ virus infection.

Concerning patient's hospitalization, more than two fifths of the study group and the control group had a positive history of hospitalization; this could be due to chronic disease and its complications, which need to seek medical care and sometimes require hospitalization. This finding is not in accordance with study conducted by Garieb (2008), about QOL and Associated Factors in Patient with C Viral Liver Disease, who mentioned that, the minority of the studied sample had a history of hospitalization.

Regarding to surgical operations, it was observed that, more than one third of the study group had past history of surgical operations compared to more than half of the control group; A finding that could be considered surgical operations, as a causative factor of disease. This finding is in accordance with Schwarzinger et al. (2004), who found that, less than one third of the patients had a history of previous surgical operations. However, Garieb (2008) mentioned that, the minority of the studied patients had a previous surgery.

As regard to anti Bilharisial treatment, about one quarter of the study group and two quarter of the control group had received anti Bilharisial treatment; this finding may could be due to the large number of patients from the rural areas and the patient's occupation as farmer. This finding is in agreement with previous study about effect of educational program for family have a member infected with HCV conducted by $\boldsymbol{A l}$ Husiny (2008), who found that, about two fifth of the studied patients had received previous anti Bilharisial treatment.

Regarding blood transfusion, the minority of the studied subjects had received blood transfusions; Blood transfusions are causative factors of $\mathrm{HCV}$ disease. Black and Hawks (2009), who found that, the minority of the studied patients had received blood transfusion, but on the other hand with Abd El-Shahed (2008), noticed that, more than one third of the studied patients had received blood transfusions. 
Concerning the history of dentist visits, the majority of the study group and the control group had a positive history of dentist visits, this is due to the use of unsterile equipment and supplies in dentist clinics are causative factors of hepatitis C. This finding is in agreement with Al Husiny (2008), who found that, about two fifth of the studied patients had a history of dentist visits.

\section{Second; Part II: The Impact of the Educational Program on the Patients'}

\section{Knowledge Scores:}

The results of the current study revealed that, there was a highly statistically significant difference in the total knowledge scores of patients with HCV among the study group with an extremely significant difference in mean knowledge scores after applying the education program. This finding could be explained by fear and anxiety of patients with hepatitis $\mathrm{C}$ about the disease process and treatment response. So these patients seek all required information and knowledge from a health care team based on their needs. The educational program prepared by the researcher to cover these patients knowledge.

Regarding the level of knowledge of the control group, there was no statistically significant difference between pre and post program. This is supported by Elshikh (2003), who conducted study about the impact of a protocol of care on physical responses and compliance among patients with congestive heart failure, he denoted that, almost three fourth of the control group had lacked some essential knowledge about their medication, action, dose, route, frequency, possible side effects and how to manage it, while the educational sessions in the group I had given a significant increase in their knowledge.

The current study results are in accordance with Sandokji et al. (2003); SarasinFilipowicz (2010); Mohsen et al. (2011), who stated that, enrichment of patient with knowledge about chronic hepatitis Cvirus, its treatment and management related interferon side effects seemed to have a positive effect on the patient's condition.

Noghabi et al., (2010) clarified that, continuous education and follow - up in chronic hepatitis C virus patients under antiviral therapy could greatly increase their adherence to treatment and reduce side effects, ultimately resulting in a better goal. 
Furthermore, Kogure, et al., (2008)conducted study on pegylated interferon plus ribavirin for genotype $\mathrm{Ib}$ chronic hepatitis $\mathrm{C}$ in japan mentioned that, patient's education and effective treatment are cornerstones for enabling patients' to adhere to treatment. In addition, lack of awareness about route of application results in early termination of treatment.

\section{Part III: The Impact of the Educational Program on Patients' Practices Scores:}

The results of the current study revealed that, there was a highly statistically significant difference in the study group after implementation of the educational program in total practice $(\mathrm{p} \leq 0.001)$, this is highly supported with Hegazy et al. (2013), who stated that, more than half of the studied sample had poor practices in pre- test and there was a highly statistically significant improvement post program.

Moreover, this is also going in the same line with Sandokji et al. (2003); SarasinFilipowicz (2010), who stated that, providing information to patients about treatment regimens, will increase their tolerance and compliance. These findings agreed also with El Hoseiny, (2005), who reported that, significant improvement of the practice of the studied patients with HCV was observed.

Regarding the level of practice for the control group, there was no statistically significant difference between pre and post program scores $(\mathrm{p} \leq 1.000)$, this is in the same line with Ibrahim and Madian (2011), who were denoted that, after program implementation the experimental group of $\mathrm{HCV}$ patients had a significant improvement of all behavior items and practice, while there is no statistical significance improvement for the control group.

Timby and Smith (2010) were mentioned that, education has a vital role in improving knowledge and practices of patients and consequently improving their QOL, this was highly supported by Nadeem et al., (2007) who were mentioned that, it's necessary to instruct patients with hepatitis $\mathrm{C}$ virus about dose adjustment during the treatment period. 


\section{CONCLUSION:}

\section{based on study findings,it can be concluded that :}

After implementation of the educational program: There was a highly statistically significant improvement in total knowledge, practice for the study group. Where in the control group there were no statistically significant differences between pre and post program scores of the control group in total knowledge and practice.

The results of this study were concluded that, patients had a lack of knowledge and practices regarding hepatitis $\mathrm{C}$, which reflected on patient's quality of life. The educational program, which was applied to the study group, has remarkable improvements in knowledge, practice, and subsequently in the patient's quality of life.

\section{RECOMMENDATIONS}

Based on the results of the current study, the following recommendations are suggested:

- Promotion and enhancement of the self-care modalities to the patient; a strict written instruction with pictures about disease process, allowed foods , rest and physical activities and follow up should be continued after termination of the treatment through a rehabilitation program.

- Awareness programs about HCV injection should be held periodically for high risk patients special attention should be given regarding teaching patients' family members who have an active role in prevention of disease transmission as well as in patient care to help them comply with the prescribed medical and nursing intervention.

- Prospective follow up studies are war warranted to develop and refine interventions to improve patient's adherence to treatment and prevent further deterioration, particularly with new antiviral therapies using oral direct acting drugs.

- Replication of the study using a large probability sample from different geographical areas to allow greater generalizability of the results.

- Recommendation concerning Ministry of Health (MOH) activities, hospitals and specialized centers' activities and increase awareness among the population at risk and general population. 
- Suggested guidelines should be available to improve nurse's knowledge and performance toward advanced technology and management of patients with hepatitis $\mathrm{C}$ virus and encourage them to teach about everything they need about hepatitis $\mathrm{C}$ virus.

\section{REFERENCES:}

Abd El-Shahed, B. (2008): Factors affecting quality of life of patients with liver cirrhosis. Unpublished Master's Thesis, Faculty of Nursing, Ain Shames University, Egypt.

Abdel Hady. (2011): Quality of life for patients with liver cirrhosis at Mansoura Hospitals. Unpublished Master's Thesis Faculty of Nursing, Zagazig University, Egypt.

Ahmed, S., \& Abdel Al, M. (2008): Predictors of health related quality of life for patients with chronic hepatitis C virus. Scientific Journal of AlAzhar Medical, Faculty of Girls; 29(2): $1639-51$.

Al Husiny, S. (2008): Effect of educational program for family have a member infected with HCV, Unpublished Master's Thesis, In Nursing Science. Faculty of Nursing, Mansoura University.

Black, J., \& Hawks, J. (2009): Medical Surgical Nursing clinical management for positive outcomes, $8^{\text {th }}$ ed., Saunders Elsevier Enc., U.S.A; P.p: 1147-1177.

El Hoseiny, S. (2005): Preventive health education for family with hepatitis C virus infected member. Unpublished Master's Thesis, Faculty of Nursing, Ain Shams University.

El-Shikh, A. (2003): The impact of a protocol of care on physical responses and compliance among patients with congestive heart failure. Unpublished Doctoral degree. Faculty of Nursing, Menoufyia University. 
Garieb, H. (2008):QoL and associated factors in patient with $\mathrm{C}$ viral liver disease. Unpublished Master's Thesis, In Nursing Science.Faculty of $\mathrm{Ng}$, Ain Shames University, Egypt.

Groessl, E.J., Weingart, K.R., \& Stepnowsky, C.J. (2011): The hepatitis C selfmanagement programme: A randomized controlled trial. Journal of Viral Hepatitis; 18: $358-368$.

Hegazy, M., Mimi, M., Mekkawy, Marwa, M., Ragheb, Hyam, R., Tantawi, Ashraf, M. \& Osman (2013): The outcome of two teaching methods on creating awareness for hepatitis C patients adherent to therapeutic regimen. Life Sci J; 10(1):73-81.

Helbling, B., Overbeck, K., Gonvers, J.J. (2008): Host-rather than virus-related factors reduce health-related quality of life in hepatitis $C$ virus infection. Gut; 57: $1597-1603$.

Ibrahim, E., \& Madian, A. (2011): Impact of hepatitis $C$ on health-related quality of life in Egypt. J Am Sci; 7(11):430-439.

Khalid, S., Khan, A., Alam, A., \& Lak, N. (2009): Interferon -Ribavirin treatment in chronic hepatitis C-the less talked about aspect. J Ayub Med CollAbbottabed; 21(2): 99-102.

Kogure, T., Ueno, Y., Fukushima, K., Nagasaki, F., \& Kondo, Y. (2008): Pegylated interferon plus ribavirin for genotype IB chronic Hepatitis C in Japan. World Gastrointestinal; 14(47): 7225-30.

Lankarani, B. (2004): How to manage side effects of interferon alpha therapy in chronic hepatitis C. J Hepat; 4(6): 5-8.

Marcellin, P., Chousterman, M., Fontanges, T., Ouzan, D., \& Rotily, M. (2011): Adherence to treatment and quality of life during hepatitis C Therapy. New HCV Drug; 28: 201- 15 . 
McHutchison, J., Goodman, Z., \& Patel, K. (2010): Farglitizar study investigators. Farglitazar lacks antifibrotic activity in patients with chronic hepatitis $\mathrm{C}$ infection. Gastroenterology; 138(4): 1365-73, 1373.

Mohsen, M., Fareed, M., El-Sheikh, A., \& Abbas, S. (2011): Effect of nursing management protocol on selected side effects of interferon and ribavirin among hepatitis C patients. Journal of American Science; 7(6): 54-63.

Nadeem, A., Aslam, M., Hussain, T., Hussain, M., \&Alikhan, S. (2007): Efficacy of combined Interferon Alpha and Ribavirin therapy in patients of chronic hepatitis $\mathrm{C}$. Pak J physical; 3(2): 1-4.

Noghabi, A., Zandi, M., Mehran, A., Alavian, S. \&Dehkardi, A. (2010): The effect of education on quality of life in patients under interferon therapy. Hepatitis Monthely; 10(3): 218-22.

Ramadan, $R$. (2006): Factors affecting self-care for patient with leukemia. Thesis of the Master Degree Medical Surgical Nursing, Ain Shams University; p.p: 58,52.

Sandokji, A., Sanai, F., Al-Ajlan, A., \&AlKarawi, M. (2003): Interferon-Ribavirin therapy for chronic hepatitis C; efficacy in Saudi patients. The Saudi Journal of Gastroenterology; 9: 129-34.

Sarasin-Filipowicz, M. (2010): Interferon therapy of hepatitis C; Molecular insights in to success and failure, Swiss Med Wekly; 140(1-2): 3-11.

Schwarzinger, M., Dewedar, S., Rekacewicz, C., Abd Elaziz, M., Fontanet, M., Carrat, F., \& Mohamed, M. (2004): Chronic hepatitis C virus infection: does it really impact health-related quality of life? a study in rural Egypt. Hepatology; 40(6): 14341441. 
Sharif, F., Mohebbi, S., Tabatabaee, H.R., Saberi-Firoozi, M., Gholamzadeh, S. (2005): Effects of psycho-educational intervention on health-related quality of life (QOL) of patients with chronic liver disease referring to Shiraz University of Medical Sciences. Health Qual Life Outcomes; 3:81.

Stefan, W., Deirdre, K., Elinne, S., \& Piotr, S. (2011): Guidance for clinical trial for children and adolescent with chronic hepatitis C. Journal of Pediatric Gastroenterology and Nutrition; 52(19):233 - 37.

Sterling, R., \& Bralow, S. (2006): Extrahepatic manifestations of hepatitis C virus. CurrGastroenterol Rep; 8(1): 53-9.

Thomas, D., \& Zoulim, F. (2012): New challenges in viral hepatitis. An International Journal of Gastroenterology and Hepatology; 61: 11-15.

Timby, \& Smith, (2010): Introduction to Medical Surgical Nursing. $10^{\text {Th }} \mathrm{ed}$, Lippincott Williams, Philadelphia, London; P.p: 704- 717.

Velmishi, V., Dervishi, E., Cullufi, p., Bali, d., \& Durro, V. (2012): Treatment and follow-up of children with chronic hepatitis C in Albania. Virology Journal; 9:17. 


\section{تقيم المعرفة والممارسات لمرضى الالتهاب الكبدى الفيروسى (C) الخاضعين للعلاج بالاتترفيرون و الريبافيرن}

شيماء محمد عبده رزق، ، ماجدة عبد العزيز محمد ،أيمن عبد الغفار الاسوقي ، دينا التابعي صبيح ماجيسنير التمريض الباطني و الجر احي- جامعة المنصورة ، أستـاذ التمـريض البـاطنـي و الجـر احيـ كلية

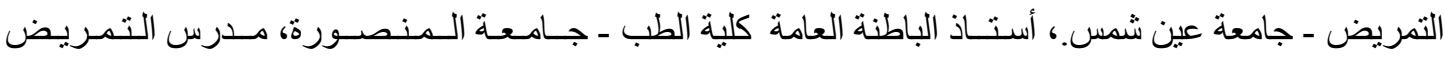

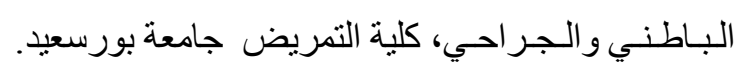

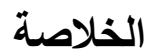

الخلفية: يعتبر مرض الالتهاب الكبدي الفيروسي (سى) من أكثر الأمراض شيوعا في الدول المنقدمة والنامية

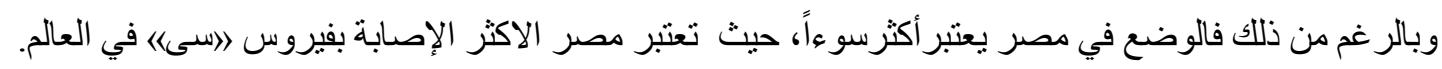

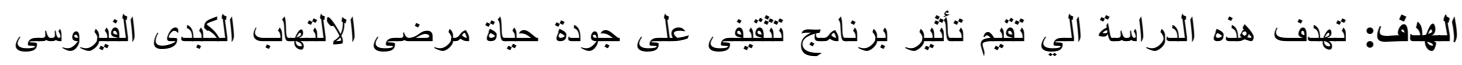

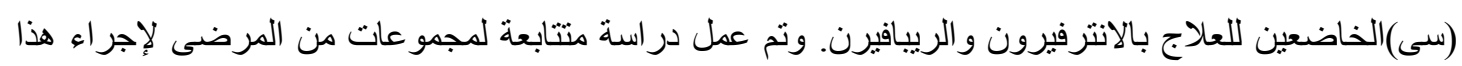
البحث. ولقد تكونت عينة الدراسة من 150 مريض (100 مريض وهى مجموعة الدراسة و50 مريض وهي مئرني

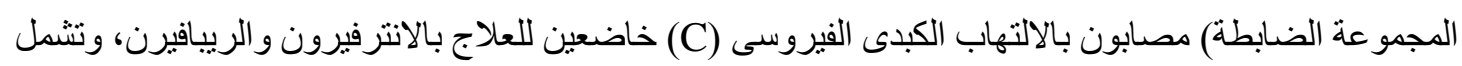
أدوات جمع البيانات: استمارة استييان والتى شملت بيانات عن خصائص المرضى الثخصيه،التاريخ الحالى الثى و السابق و تقييم مستوي المعرفة و الممارسات الخاصة بهؤلاء المرضى ـ وقد أظهرت نتائج الدراسة تحسن إيجابي إحصائي ملحوظ بعد تتفيذ البرنامج التعليمي للمرضى فى عينة الدراسة في معلومات المرضى وسلوكياتهم.أما

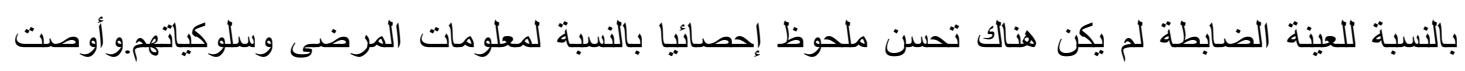
الدراسة متابعة الابحاث العلمية الحديثة والدراسات المستقلية التى تساعد على تحسن المرضى وذيادة إستجابتهم للعلاج.

الكعـــات الاسترشادييه :الالتهاب الكبدى الفيروسى (C) ،المعرفة ، السلوكيات ،الانترفيرون ، الريبافيرن، برنامج تعليمى، 